\title{
In vitro anti-oxidant, anti-wrinkle and whitening effect of solvent fraction from takli-san
}

\author{
Jae-Myo Yu ${ }^{1}$ - Yun-Hwan Kang ${ }^{1}$ Dong-Hee Kim ${ }^{1} \cdot$ Tae-Soon Park $^{1}$ \\ 탁리산 용매 분흭물의 in vitro 항산화, 주름 억제 및 미백 효과
}

유재묘 ${ }^{1}$ - 강윤환 ${ }^{1}$ - 김동희 ${ }^{1} \cdot$ 박태순 $^{1}$

Received: 22 June 2017 / Accepted: 24 July 2017 / Published Online: 30 September 2017

(C) The Korean Society for Applied Biological Chemistry 2017

\begin{abstract}
In this study, the activity of Takli-san for anti-oxidation, anti-wrinkle and whitening effect was verified and its applicability as a cosmetic material was confirmed. 1-1-diphenyl-2-picrylhydrazyl radical scavenge, 2,2'-azinobis(3-ethylbenzothiazoline-6sulfonic acid) radical scavenge, elastase and tyrosinase inhibitory activity were investigated by solvent fraction, and ethyl acetate fraction of water extract from Takli-san (TW-EA) showed the highest inhibitory activity. Western blot was performed to confirm anti-wrinkle and whitening effect in the cells, and it was investigeted that the TW-EA inhibition effect was superior to that of the positive contol used for the comparison test. Through the results of the experiments, the applicability as a cosmetic material of Takli-san was verified.
\end{abstract}

Keywords Anti-oxidant $\cdot$ Anti-wrinkle $\cdot$ CCD-986sk $\cdot$ HEM · Takli-san · Whitening

Tae-Soon Park $(\bowtie)$

E-mail: taesoon2p@nikom.or.kr

${ }^{1}$ National Development Institute of Korean Medicine, Gyeongsan 712-260, Republic of Korea

This is an Open Access article distributed under the terms of the Creative Commons Attribution Non-Commercial License (http://creativecommons. org/licenses/by-nc/3.0/) which permits unrestricted non-commercial use, distribution, and reproduction in any medium, provided the original work is properly cited.

\section{서 론}

노화란 기능적, 구조적, 생화학적으로 신체 조직 및 세포 전 기 관에 걸쳐 일어나는 변화라고 말할 수 있다. 피부의 노화는 내 인성 노화(intrinsic aging)와 광노화(photoaging)에 의해 나타나 며 이로 인해 주름과 색소침착이 증가하게 된다(Gilchrest 1990; Ha 2006).

노화의 원인으로써 reactive oxygen species (ROS)를 들 수 있 는데 세포 및 조직에서 생성되어 생체 내에 존재하는 superoxide distimutase (SOD), peroxidase, catalase 등에 의해 대부분 소멸 된다. 그러나 ROS가 제대로 제거되지 않을 경우 free radical로 인한 산화적 스트레스를 받게 되므로 생체는 노화를 비롯한 각 종 질병이 유발 되기도 한다(Karin 등, 2000; Meinhard 2001). 또한, 광노화의 주요인자인 자외선에 의해서도 ROS가 생성되 는데, 이는 collagen 감소, elasatin 변성, 단백질 산화 등을 유 발하거나(Yaar와 Gilchrest 2007), matrix metalloproteinase (MMP)의 생성을 증가시켜 주름을 유발한다(Charous 등, 1997; So 등, 2008).

또한, 자외선은 주름뿐만 아니라 색소침착을 증가시키는데, 이것은 자외선에 의한 피부 세포 손상을 억제할 목적으로 melanin이 생성된 결과이다. 체내에서 melanin의 합성은 melanocyte 에서 cyclic adenosine monophosphate/protein kinase A 경로 에 의해 합성된다(Ha 2009). 여기서 microphthalmia-associated transcription factor (MITF)는 melanogenic gene promoters들에 결합 및 활성화하여 tyrosinase, tyrosinase related protein (TRP)-1, TRP-2의 발현을 촉진시킴으로써 최종적으로 melanin synthesis를 유발한다(Busca와 Ballotti 2000; Saha 등, 2006).

한방에서는 피부노화, 미백 등과 같은 피부 미용에 관한 관 심이 증가되고 있으며 그에 따라 기존 처방을 이용한 한방화장 품 등이 개발되고 있다. 개발 과정에서 경구처방이 사용되는 사 례가 많은데, 이 처방은 고전 문헌 또는 임상 치료의 결과에서 
내복약 위주의 데이터를 확보해왔기 때문에 피부에 도포하는 경 피용 소재로서 검증은 미비하다고 할 수 있다(Kim 등, 2015). 기존에 한약처방으로 보고된 연구로는 연교승마탕 $(\mathrm{Kim}$ 등, 2008a), 황연해독탕(Yun 등, 2008), 경옥고 가미방(Choi 등, 2007), 신효탁리산(Kang 등, 2016) 등이 있다. 본 연구에서는 탁리산을 이용하여 연구하고자 한다.

탁리산은 인삼(人鉒), 황기(黃芪), 백작약(白苟藥), 백출(白术), 진피(陳皮), 당귀(當歸), 숙지황(熟地黃), 백복령(白获), 감초(甘草) 총 9가지 약재로 구성되어있고, 《동의보감(東醫寶鑑)》에서 옹 저(痽疽)가 기혈(氣血)이 허하여서 나올 수가 없고 나온 것들도 다시 수렴되며 추운 것을 싫어하고 열(熱)이 나며 기육(肌肉)이 영양을 원활히 받지 못하는 것을 치료하는 데에 쓰던 처방으로 기재되어 있다. 현재까지 연구결과로는 마우스를 이용한 항암효 능 연구(Choi 등, 2005), Balb/c 3T3의 증식에 미치는 영향 연 구(Eun 등, 1993), 보습 효능에 대한 임상적 연구(Kang 등, 2016) 등이 보고되어 있다.

본 연구에서는 탁리산 열수추출물의 용매 분획물을 이용하여 항산화, 주름억제, 미백효과에 대한 활성을 검증하였다.

\section{재료 및 방법}

\section{재료 및 시약}

본 실험에 사용한 구성 약재는 2016년 2월 (주)휴먼허브 (Gyeongsan, Korea)에서 구입하여 실험 재료로 사용하였다. 효 능 실험과 세포 독성 측정 시약 1-1-diphenyl-2-picryl-hydrazyl (DPPH), 2,2'-azinobis(3-ethylbenzothiazoline-6-sulfonic acid) (ABTS), potassium persulfate, porcine pancreas elastase, Lascorbic acid, L-3,4-dihydroxyphenylalanine (L-DOPA), nsuccinyl-(L-Ala) ${ }_{3}$-p-nitroanilide, collagenase from Clostridium histolyticum, 3-[4,5-dimethylthiazol-2-yl]-2,5-diphenyl-tetrazolium bromide (MTT)은 Sigma chemical Co. (St. Louis, MO, USA) 에서 구입하여 사용하였다. 세포 배양에 사용되는 dulbecco's modified eagle medium (DMEM), fetal bovine serum (FBS), penicillin/streptomycin, $0.25 \%$ trypsin-EDTA, $0.4 \%$ trypan blue stain은 gibco BRL Co. (Grand Island, New York, USA), haemacytometer (Marienfeld, Lauda-Königshofen, Germany)를 구입하 였다. Melanin 생성 유발을 위한 human tumor necrosis factor- $\alpha$ with carrier, sterile (TNF- $\alpha$ )는 Cell Signaling사(Danvers, MA, USA)에서 구입하여 사용하였다. 주름 및 항산화활성 측정을 위 해 procollagen type I C-peptide kit (Takara Shuzo, Kyoto, Japan)와 ROS-Glo ${ }^{\mathrm{TM}} \quad \mathrm{H}_{2} \mathrm{O}_{2}$ assay kit (Promega, Madison, WI, USA)를 구입하여 사용하였다. Primary antibody인 MMPs 및 tyrosinase, MITF, TRP-1, TRP-2와 secondary antibody는 Santa cruz biotechnology Inc. (Santa Cruz, CA, USA)에서 구입하였다.

\section{시료 추출 및 용매 분흭}

인삼(人蓼) $8 \mathrm{~g}$, 황기(黃芪), 백출(白尤), 진피(陳皮), 당귀(當歸), 숙지황(熟地黃), 감초(甘草)를 각각 $4 \mathrm{~g}$, 백복령(白获), 백작약(白 苟藥)을 각각 $2 \mathrm{~g}$ 계량하고, 이것의 3 회 분량의 시료 중량에 10 배의 물을 넣어 환류추출기에서 3시간씩 3회 반복 추출한 다음 filter paper (Whatman No. 2, Tokyo, Japan)로 여과하고 감압 농축기로 농축하여 추출물 $29.3 \mathrm{~g}$ 을 얻었다. 그중 $14 \mathrm{~g}$ 을 가지 고 순차적 용매분획법을 이용하여 $\mathrm{n}$-hexane 분획물 $(0.67 \mathrm{~g})$, ethyl acetate 분획물 $(1.1 \mathrm{~g})$, butanol 분획물 $(4.57 \mathrm{~g})$ 최종 물분획 물 $(7.5 \mathrm{~g})$ 을 확보하였다.

\section{세포배양}

본 실험에 사용된 세포주는 fibroblast인 CCD-986sk cell과 melanocyte인 HEM cell을 American Type Culture Collection (ATCC, Rockville, MD, USA)에서 구입하여 사용하였다. 세포 의 배양은 $10 \% \mathrm{FBS}$ 와 $1 \%$ penicillin/streptomycin $(100 \mathrm{U} / \mathrm{mL})$ 을 첨가한 $\mathrm{DMEM}$ 배지와 human melanocyte growth medium (CEFO, Seoul, Korea)에 $1 \%$ penicillin/streptomycin $(100 \mathrm{U} / \mathrm{mL})$ 를 첨가한 배지를 각각 사용하였으며, $37^{\circ} \mathrm{C}, 5 \% \mathrm{CO}_{2}$ incubator 에서 배양하였다.

\section{MTT assay에 의한 세포 독성 측정}

세포 독성 측정은 Carmichael 등(1987)의 방법에 따라 측정하 였다. CCD-986sk cell과 $\mathrm{HEM}$ cell을 각각 96 well plate에 $1 \times 10^{4}, 3 \times 10^{4}$ cells/well을 분주하고 $37^{\circ} \mathrm{C}, 5 \% \mathrm{CO}_{2}$ incubator 에서 24 시간 배양하였다. 새 $\mathrm{DMEM}$ 을 $200 \mu \mathrm{L}$ 넣고 시료를 농 도 별로 처리한 후 $37{ }^{\circ} \mathrm{C}, 5 \% \mathrm{CO}_{2}$ incubator에서 48 시간 동안 배양하였다. 여기에 $5 \mathrm{mg} / \mathrm{mL}$ 농도로 제조한 MTT 용액 $20 \mu \mathrm{L}$ 를 첨가하여 4시간 배양한 후 배양액을 제거하고 각 well에 DMSO $150 \mu \mathrm{L}$ 를 가하여 실온에서 30 분간 반응 시킨 뒤 microplate reader로 $540 \mathrm{~nm}$ 에서 흡광도를 측정하였다. 세포 독성 측정은 시료용액의 첨가군와 무첨가군의 흡광도 감소율 $(\%)$ 로 나타내었다.

\section{DPPH radical scavenging activity 측정}

$\mathrm{DPPH}$ radical 소거능에 대한 실험은 Blois 등 (1958)을 변형하 여 96 well plate를 이용하여 측정하였다. 각 시료 $100 \mu \mathrm{L}$ 에 $0.2 \mathrm{mM}$ 의 $\mathrm{DPPH}$ 용액 $50 \mu \mathrm{L}$ 를 넣고 교반 한 후 10 분간 방치 한 다음 $517 \mathrm{~nm}$ 에서 흡광도를 측정하였으며, 시료용액의 첨가 구와 무첨가구 사이의 흡광도의 차이를 백분율 $(\%)$ 로 나타냈다.

\section{ABTS radical scavenging activity 측정}

ABTS radical 소거능을 이용한 항산화력 측정은 $\operatorname{Re}$ 등 (1999) 의 방법을 이용하여 측정하였다. $7 \mathrm{mM} \mathrm{2,2'-azino-bis(3-ethyl-}$ benzothiazoline-6-sulfonic acid)와 $2.45 \mathrm{mM}$ potassium persulfate 를 혼합하여 실온에서 24시간 동안 방치하여 $\mathrm{ABTS}^{+}$를 형성시 킨 후 ethanol로 1:9로 희석하여 사용하였다. 각 시료 $50 \mu \mathrm{L}$ 에 희석한 $\mathrm{ABTS}$ 용액 $100 \mu \mathrm{L}$ 를 가하여 5 분 동안 방치한 후 734 $\mathrm{nm}$ 에서 흡광도를 측정하였다.

\section{ROS 생성량 측정}

ROS-Glo ${ }^{\mathrm{TM}} \mathrm{H}_{2} \mathrm{O}_{2}$ assay kit를 사용하여 제조사의 매뉴얼에 따 라 ROS 발생량을 측정하였다. CCD-986sk cell을 이용하여 96well plate에 각 well 당 $1 \times 10^{4}$ cells/well 세포가 되도록 분주 한 후 24시간 동안 배양하였다. 이후, 배양된 배지를 제거하고 $\mathrm{PBS}$ 를 넣어 UV-B $\left(20 \mathrm{~mJ} / \mathrm{cm}^{2}\right)$ 를 처리하고 $\mathrm{PBS}$ 를 제거한뒤 $\mathrm{DMEM}$ 배지를 각 well에 넣고 $\mathrm{TNF}-\alpha$ 를 $10 \mathrm{ng} / \mathrm{mL}$ 의 농도로 첨가한 후 시료를 농도별로 처리하여 48시간 동안 배양하고 
ROS 발생양을 microplate reader를 사용하여 측정하였다.

\section{Elastase 저해활성 측정}

Elastase 저해활성은 Cannell 등 (1998)의 방법에 따라 측정하였 다. 동일 농도의 시료를 조제하여 $40 \mu \mathrm{L}$ 씩 96 well plate에 분 주하고, $50 \mathrm{mM}$ tris- $\mathrm{HCl}$ buffer $(\mathrm{pH}$ 8.6)에 녹인 $2.5 \mathrm{U} / \mathrm{mL}$ porcine pancreas elastase 용액을 $40 \mu \mathrm{L}$ 가한 후 기질로 $50 \mathrm{mM}$ tris- $\mathrm{HCl}$ buffer (pH 8.6)에 녹인 n-succinyl-(L-Ala) $)_{3}$-pnitroanilide $(0.5 \mathrm{mg} / \mathrm{mL})$ 을 첨가하여 30 분 간 반응시킨 후 $445 \mathrm{~nm}$ 에서 측 정하였다. Elastase 저해활성은 시료용액의 첨가구와 무첨가구의 흡광도 감소율 $(\%)$ 로 나타내었다.

\section{Procollagen type-I 생합성 측정}

CCD-986sk cell $1 \times 10^{4}$ cells/well 을 96 well plate에 접종한 후 24시간 동안 배양하였다. 그 후 UV-B $\left(20 \mathrm{~mJ} / \mathrm{cm}^{2}\right)$ 를 조사 하고 $\mathrm{TNF}-\alpha$ 를 $10 \mathrm{ng} / \mathrm{mL}$ 의 농도로 처리한 후 각 well에 시료 를 첨가하여 48시간 동안 배양하였다. 이렇게 배양한 세포의 배 양액을 채취하여 procollagen type-C peptide (PIP) EIA kit (Takara Bio)를 사용하여 propeptide의 양을 측정하였다.

\section{Tyrosinase 저해활성 측정}

Tyrosinase 저해활성 측정은 Yagi 등(1986)의 방법에 따라 측정 하였다. 반응구는 $0.175 \mathrm{M}$ sodium phosphate buffer $(\mathrm{pH}$ 6.8) $500 \mu \mathrm{L}$ 에 $10 \mathrm{mM} \mathrm{L-DOPA}$ 를 녹인 기질액 $200 \mu \mathrm{L}$ 및 시료 $100 \mu \mathrm{L}$ 의 혼합액에 mushroom tyrosinase $(110 \mathrm{U} / \mathrm{mL}) 200 \mu \mathrm{L}$ 을 첨가하여 $25^{\circ} \mathrm{C}$ 에서 2 분간 반응시켜 반응액 중에 생성된 DOPA chrome을 $492 \mathrm{~nm}$ 에서 측정하였다. tyrosinase 저해활성 은 시료용액의 첨가구와 무첨가구의 흡광도 감소율 $(\%)$ 로 나타 내었다.

\section{Western blot을 통한 주름 및 미백 관련 단백질의 발현 측정} CCD-986sk cell을 6 well plate에 $1 \times 10^{5}$ cells/well이 되도록 분주하고 24 시간 동안 배양하였다. 그 후 $\mathrm{PBS}$ 로 교환하여 UV$\mathrm{B}\left(20 \mathrm{~mJ} / \mathrm{cm}^{2}\right)$ 를 조사하고 다시 배지교환 후, $\mathrm{TNF}-\alpha$ 를 $10 \mathrm{ng}$ $\mathrm{mL}$ 의 농도로 첨가하고 시료를 농도별로 처리하여 48시간 동안 배양한 후 차가운 PBS로 세척하였다. HEM cell은 6 well plate에 $3 \times 10^{5}$ cells/well로 분주하여 24 시간 동안 배양하였고, 그 후 DMEM 배지로 교환하고 forskolin $(1 \mathrm{nM})$ 과 시료를 처리하 여 48시간 동안 배양하였다. 세포는 lysis buffer를 well 당 30 $\mu \mathrm{L}$ 를 첨가하여 세포를 용해시키고 원심분리하여 $(12,000 \mathrm{rpm}$, $4{ }^{\circ} \mathrm{C}, 20 \mathrm{~min}$ ) 단백질을 추출하였다. 원심분리하여 얻은 단백질 은 bradford assay로 정량하였으며, 동일양의 단백질을 $10 \%$ 의 $\mathrm{SDS}-\mathrm{PAGE}$ 를 이용하여 전기영동한 후, PVDF membrane에 transfer하였다. PVDF membrane을 $1 \times \mathrm{TBST}$ 에 녹인 5\% BSA 에 1 시간 동안 반응시켜 background를 제거하고 TBST로 3회 washing 한 후 primary antibody (1:500)를 1시간 동안 반응시 켰다. 그 후 secondary antibody (1:500)를 2.5시간 동안 반응 시키고 TBST로 3회 washing 한 후 Immobilon chemiluminescent reagents로 측정하였다. Band density는 ImageQuant LAS-4000 (GE life sciences, Taipei, Taiwan)으로 확인하였다.

\section{통계처리}

통계처리는 SPSS 10.0 을 사용하였으며, 유의차 검증은 분산분 석(ANOVA: analysis of variance) 프로그램을 이용하여 $t$-test를 통해 통계적 유의수준 $p<0.05$ 에서 검증하였다.

\section{결과 및 고찰}

\section{MTT assay에 의한 세포 독성}

탁리산 열수추출물의 에틸아세테이트 분획물(TW-EA)로 CCD986sk cell과 HEM cell에서 세포 독성을 확인하기 위하여 시료 를 $6.25,12.5,25,50,75,100,200 \mu \mathrm{g} / \mathrm{mL}$ 의 농도로 처리하 여 관찰하였다. 그 결과 CCD-986sk cell은 $6.25-100 \mu \mathrm{g} / \mathrm{mL}$ 농 도에서는 세포 독성을 확인 할 수 없었고, $200 \mu \mathrm{g} / \mathrm{mL}$ 이상에서 독성이 관찰되었다. HEM cell의 경우 $100 \mu \mathrm{g} / \mathrm{mL}$ 농도 이상에 서 세포독성이 관찰되었다(Fig. 1).

\section{항산화 활성}

시료의 항산화 효과를 검증하기 위해 $\mathrm{DPPH}, \mathrm{ABTS}$ radical 소 거능 측정, $\mathrm{ROS}-\mathrm{Glo}^{\mathrm{TM}} \mathrm{H}_{2} \mathrm{O}_{2}$ assay kit를 이용한 $\mathrm{ROS}$ 생성량 측정을 수행하였다. $\mathrm{DPPH}$ 는 라디칼 전자의 비편재화에 의해 안정한 구조의 라디칼로 존재하는 화합물 내 질소 중심의 라디 칼이다. $517 \mathrm{~nm}$ 에서 최대 흡수를 하며, 환원되면 $517 \mathrm{~nm}$ 에서 흡수가 없어지므로 $\mathrm{DPPH}$ 의 환원정도는 환원제의 환원력에 달 려있다고 할 수 있다(Lee 2011). 기존 보고에서 제주 자생 조 록나무 분획물의 $\mathrm{DPPH}$ 라디칼 소거능 측정결과 에틸아세테이 트 분획물(EA)이 $100 \mu \mathrm{g} / \mathrm{mL}$ 의 농도에서 약 $50 \%$ 의 소거능을 보여주었고( $\mathrm{Kim}$ 등, 2016$)$, 사과꽃잎 $70 \%$ 에탄올 추출물의 $\mathrm{EA}$ 는 $100 \mu \mathrm{g} / \mathrm{mL}$ 에서 약 $58 \%$ 의 저해활성을 나타내었다(Choi 등, 2011). 탁리산 열수추출물의 헥산(TW-H), 에틸아세테이트(TW$\mathrm{EA})$, 부탄올(TW-B), 물(TW-W) 분획물은 $100,1,000 \mu \mathrm{g} / \mathrm{mL}$ 의 농도에서 각각 $19,62,43,22 \%$ 와 $33,92,90,83 \%$ 의 소거능 을 나타내었고, 그 중 TW-EA의 효과가 가장 우수했다(Fig. 2A). $\mathrm{TW}-\mathrm{EA}$ 의 $\mathrm{RC}_{50}$ 값은 $75.4 \pm 4.2 \mu \mathrm{g} / \mathrm{mL}$ 로 측정되었다.

ABTS radical 소거능 측정법은 항산화물질의 수소 이온 공여

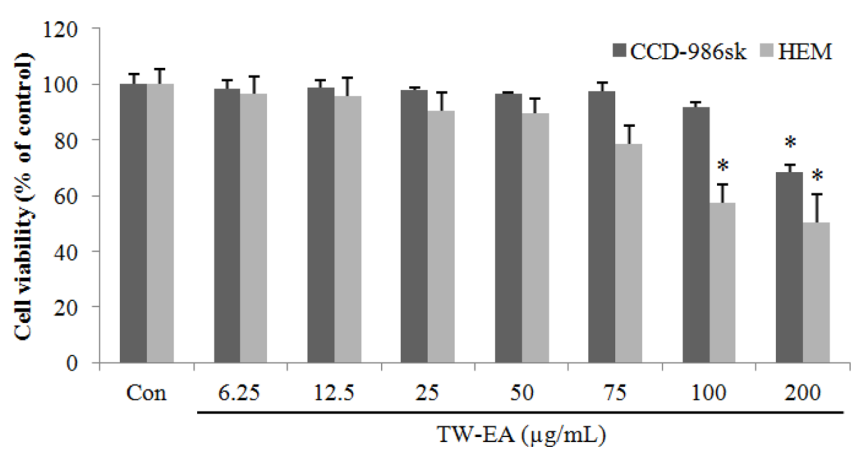

Fig. 1 Cytotoxicity of cell (CCD-986sk and HEM) of solvent fraction isolated from Takli-san. $\square$ : CCD-986sk cell. W: HEM cell. TW-EA: ethyl acetate fraction of water extract from Takli-san. Result are means \pm SD of triplicate data. ${ }^{*} p<0.05$ vs. Con 

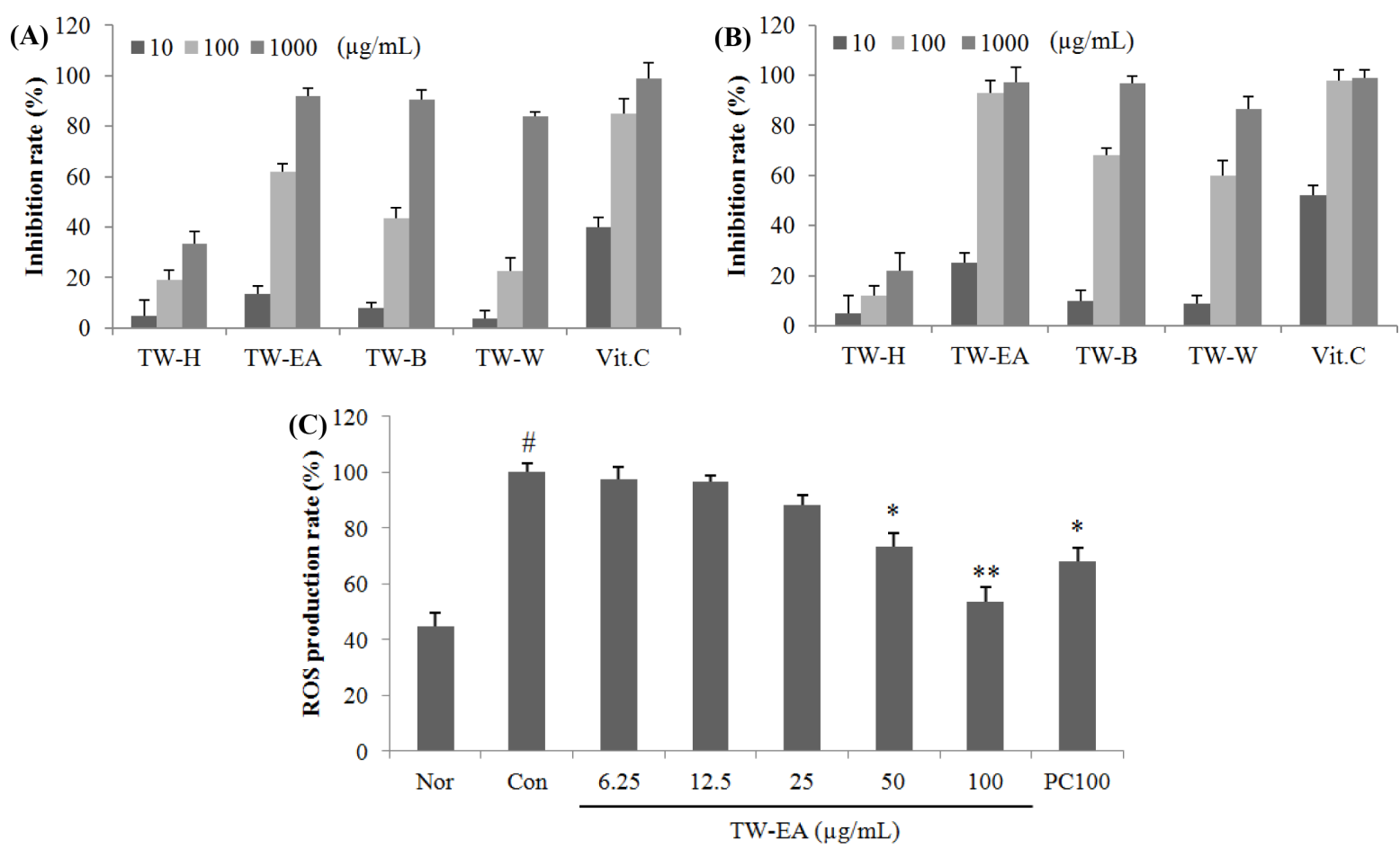

Fig. 2 Anti-oxidant activity of solvent fractions isolated from Takli-san. (A) DPPH radical activity. (B) ABTS cation radical activity. (C) ROS production rate. TW-H: hexane fraction of water extract from Takli-san. TW-EA: ethyl acetate fraction of water extract from Takli-san. TW-B: butanol fraction of water extract from Takli-san. TW-W: water fraction of water extract from Takli-san. Vit. C: L-ascorbic acid. PC100: treatment of adenosine by $100 \mu \mathrm{g} / \mathrm{mL}$. Result are means $\pm \mathrm{SD}$ of triplicate data. ${ }^{\sharp} p<0.05$ vs. non-treated Nor. ${ }^{*} p<0.05,{ }^{* *} p<0.01$ vs. Con

능을 측정하는 분석법으로 과황산칼륨과 반응에 의해 생성된 $\mathrm{ABTS}^{+}$자유라디칼이 시료속의 항산화 물질에 의해 제거되어 라디칼 특유의 색인 청록색이 탈색되는 것을 이용하여 항산화 효과를 측정한다 $(\operatorname{Re}$ 등, 1999$)$. 구절초 꽃의 항산화 활성 연구 에서는 메탄올추출물의 $\mathrm{EA}$ 에서 약 $65 \%(100 \mu \mathrm{g} / \mathrm{mL})$ 로 보고되 었고(Hyun 등, 2011), 무청 에탄올 추출물의 EA는 약 $43 \%$ 의 소거능을 나타내었다(Lee 등, 2013). TW-H, TW-EA, TW-B, $\mathrm{TW}-\mathrm{W}$ 는 100 과 $1,000 \mu \mathrm{g} / \mathrm{mL}$ 의 농도에서 소거활성이 각각 12 , $93,68,60 \%$ 와 $22,97,96,86 \%$ 로 나타나서 더 높은 소거능을 확인하였고, 분획물 중에서는 TW-EA의 효과가 가장 높게 나타 났다(Fig. 2B). TW-EA의 $\mathrm{RC}_{50}$ 값은 $40.8 \pm 3.7 \mu \mathrm{g} / \mathrm{mL}$ 로 측정되 었다.

UV-B에 노출된 피부는 활성산소종(ROS)을 생성하는데 이것 은 세포내에 영향을 주어 피부손상을 주기 때문에 이것의 제거 능을 검증하기 위해(Fisher 등, 1997; Yoon 등, 2003; Di Girolamo 등, 2006; Shimauchi 등, 2008; Han 등, 2013), ROS를 유도 한 뒤 $\mathrm{DPPH}$ 와 $\mathrm{ABTS}$ raical 소거능 측정결과에서 가장 우수한 효능을 나타낸 TW-EA를 농도별로 처리하여 항산화능을 측정 하였다. 그 결과 농도의존적으로 감소하는 것을 확인하였고 100 $\mu \mathrm{g} / \mathrm{mL}$ 의 농도에서 $46.4 \%$ 의 저해효과를 보여주었다(Fig. $2 \mathrm{C}$ ).

\section{주름 억제}

시료의 주름억제 효능을 검증하기 위해 elastase 억제활성과 PIP 생성량 확인 및 collagen 분해를 통한 광노화 유도 인자인 MMPs에 대해 western blot을 실시하였다. 피부 주름은 진피에
존재하는 collagen과 elastin의 그물망 구조가 깨지면서 일어나 는데, 이것은 자외선, 나이 그리고 스트레스 등으로 인해 과발 현된 elastase에 의해서 이루어진다(Voegeli 1996). 따라서 탁리 산 용매 분획물로 elastase의 억제율을 측정하여 주름억제 활성 을 검증하였으며 TW-H, TW-EA, TW-B, TW-W는 $1,000 \mu \mathrm{g} /$ $\mathrm{mL}$ 의 농도에서 각각 $29,49,26,32 \%$ 의 억제율을 나타냈고 TW-EA가 용매 분획물 중 가장 높은 저해활성을 보여주었다 (Fig. 3A). 동일한 농도에서 선학초 $\mathrm{EA}$ 는 약 $53 \%$ 의 억제효과 를 나타내었고(Yoon 등, 2012), 오이풀 뿌리 분획물의 약리활성 연구에서는 $70 \%$ 아세톤으로 추출한 오이풀 뿌리의 $\mathrm{EA}$ 가 $1,000 \mu \mathrm{g} / \mathrm{mL}$ 의 농도에서 약 $21 \%$ 의 억제율을 보여주었다(Jang 등, 2012).

CCD-986sk cell에 elastase 억제활성 측정결과 가장 우수한 효능을 나타낸 TW-EA를 이용하여 procollagen의 합성양을 평 가하기 위해 PIP EIA kit를 이용하여 free propeptide 생성양을 검출하였다. Collagens는 procollagens이라고 불리는 전구체로 합 성되고 이것은 propeptides라고 불리는 펩타이드 서열을 포함하 고 있다(Kim 등, 2008b). 따라서 free propeptide의 양은 합성 된 collagen 분자의 양을 말한다. TW-EA를 농도별로 처리하여 확인한 결과 최고 농도인 $100 \mu \mathrm{g} / \mathrm{mL}$ 의 농도에서 각 각 $89 \%$ 의 procollagen 합성율을 나타내었다(Fig. 3B).

주름관련 단백질 발현을 검증하기 위해 western blot을 실시 하였으며, 주름이 생성되는 원인으로 교원질의 결핍을 들 수 있 는데 이것은 진피의 주요 구성물질이며 특히 광노화된 피부에 서 MMP-1, -2, -9, 13 등과 같은 효소의 작용으로 인해 주름 

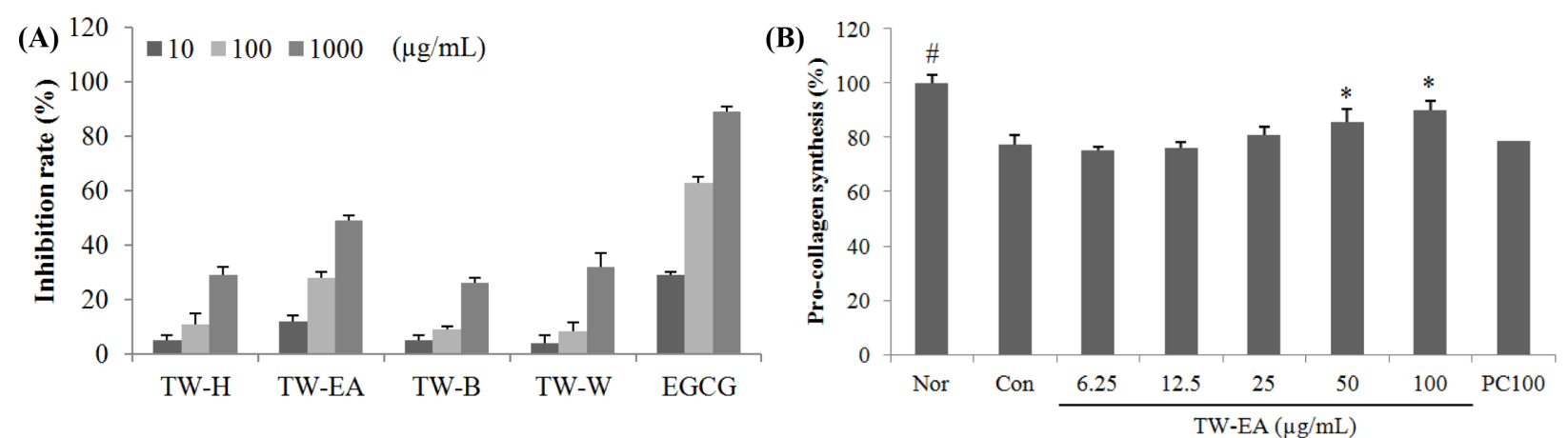

Fig. 3 Anti-wrinkle activity of solvent fractions isolated from Takli-san. (A) Elastase inhibition rate. (B) procollagen synthesis rate. TW-H: hexane fraction of water extract from Takli-san. TW-EA: ethyl acetate fraction of water extract from Takli-san. TW-B: butanol fraction of water extract from Takli-san. TW-W: water fraction of water extract from Takli-san. EGCG: epigallocate chin-3-gallate. PC100: treatment of adenosine by $100 \mu \mathrm{g} / \mathrm{mL}$. Result are means \pm SD of triplicate data. ${ }^{*} p<0.05$ vs. Con. ${ }^{*} p<0.05$ vs. non-treated Nor
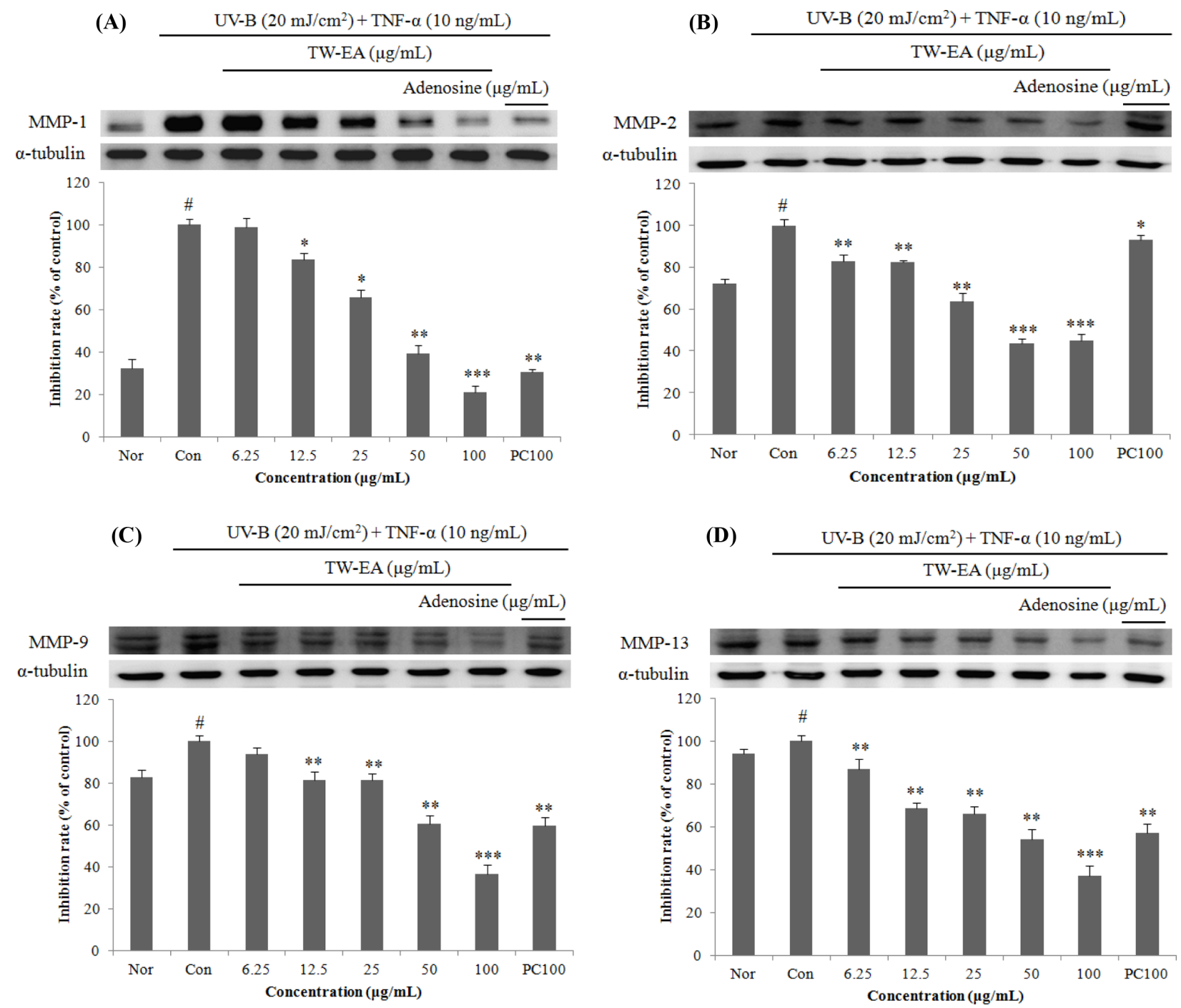

Fig. 4 Wrinkle-related protein expression rate of Takli-san on fibroblast cell (CCD-986sk). Histogram show the densitometry of protein normalized to $\alpha$-tubulin. (A) MMP-1 protein expression rate. (B) MMP-2 protein expression rate. (C) MMP-9 protein expression rate. (D) MMP-13 protein expression rate. PC100: treatment of adenosine by $100 \mu \mathrm{g} / \mathrm{mL}$. The data represent the mean \pm SD of three separate experiments. ${ }^{\#} p<0.05$ vs. nontreated Nor. ${ }^{*} p<0.05,{ }^{* *} p<0.01$ and ${ }^{* * *} p<0.001$ vs. Con 


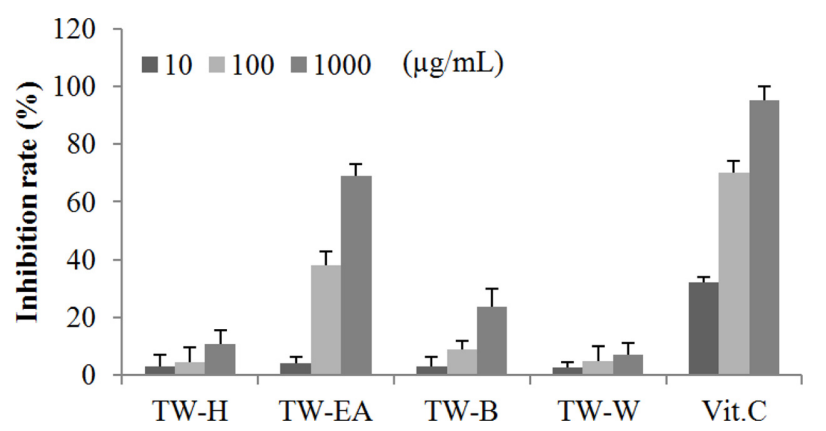

Fig. 5 Tyrosinase inhibition rate of solvent fractions isolated from Taklisan. TW-H: hexane fraction of water extract from Takli-san. TW-EA ethyl acetate fraction of water extract from Takli-san. TW-B: butanol fraction of water extract from Takli-san. TW-W: water fraction of water extract from Takli-san. Vit. C: L-ascorbic acid. Result are means \pm SD of triplicate data
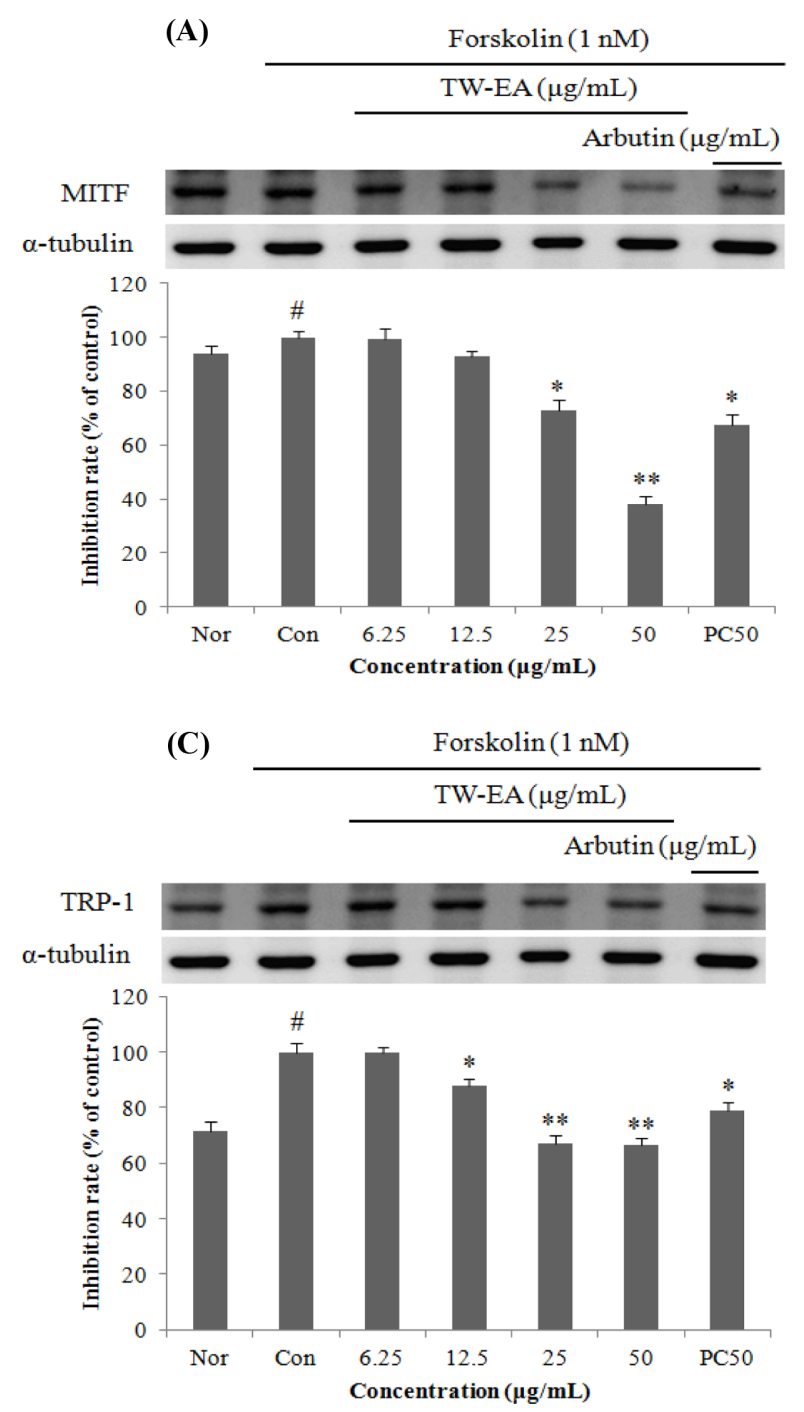

을 형성하게 된다(Seo 등, 2001).

CCD-986sk cell에 TW-EA를 농도 별로 처리하여 MMP-1, -2, $-9,13$ 의 활성을 확인하였으며 각 각 $100 \mu \mathrm{g} / \mathrm{mL}$ 의 농도에서 79 , $55,64,63 \%$ 의 저해활성을 보여주었다(Fig. 4 ).

\section{미백 활성}

시료의 미백 효과를 검증하기 위해 tyrosinase 저해활성과 western blot을 실시하였다. Tyrosinase는 melanin 생성에 중요 한 역할을 하는 효소로 기질인 tyrosine이 tyrosinase에 의해 산 화되어 생성되는 melanin의 흡광도를 측정함으로써 시료의 tyrosinase 억제 활성 효과를 검토하는 방법으로 미백 효과 연 구에 사용되고 있다(Ko 등, 2012). 기존에 보고된 연구로는 구 아바잎 $70 \%$ 메탄올 추출물의 $\mathrm{EA}$ 이 $1,000 \mu \mathrm{g} / \mathrm{mL}$ 에서 $65 \%$ 의 저해활성을 나타내었고(Park과 Onjo 2008), 섬초롱 $80 \%$ 에탄올 추출물의 $\mathrm{EA}$ 는 동일한 농도에서 약 $25 \%$ 의 억제효과를 보여주

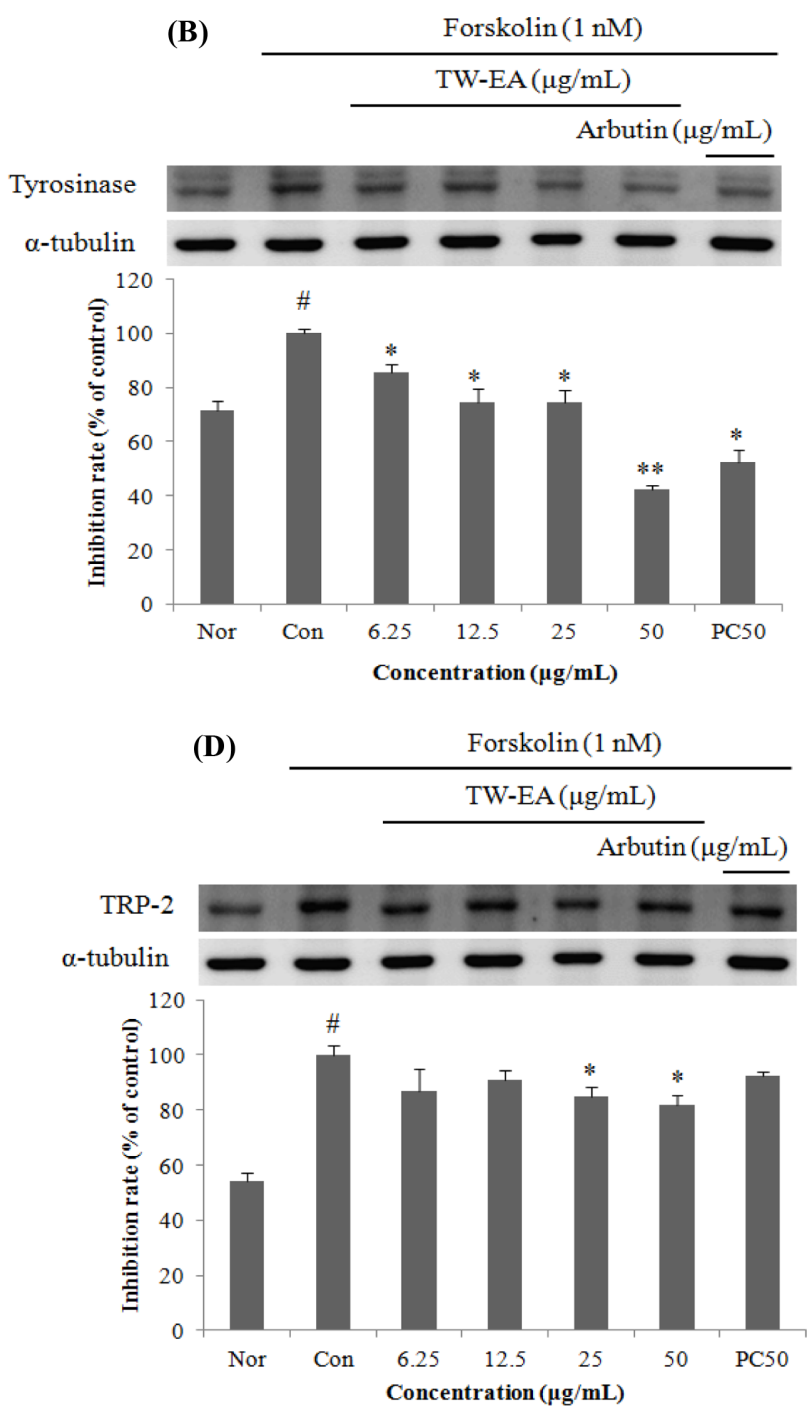

Fig. 6 Whitening-related protein expression rate of Takli-san on melanocyte cell (HEM). Histogram show the densitometry of protein normalized to $\alpha$ tubulin. (A) MITF protein expression rate. (B) Tyrosinase protein expression rate. (C) TRP-1 protein expression rate. (D): TRP-2 protein expression rate. PC50: treatment of arbutin by $50 \mu \mathrm{g} / \mathrm{mL}$. The data represent the mean $\pm \mathrm{SD}$ of three separate experiments. ${ }^{*} p<0.05$ vs. non-treated Nor. ${ }^{*} p<0.05$ and ${ }^{* *} p<0.01$ vs. Con 
었다(Kim 등, 2012). 반면 탁리산 용매 분획물은 TW-H, TW$\mathrm{EA}, \mathrm{TW}-\mathrm{B},-\mathrm{TW}-\mathrm{W}$ 이 동일한 농도에서 각각 $10,69,23,7 \%$ 의 저해활성을 나타내었고, 그 중 TW-EA가 가장 우수한 효능 을 나타내었다(Fig. 5).

미백 관련 단백질 발현을 확인하기 위해 western blot을 실시 하였고, melanin은 기저층에 존재하는 melanocyte에서 생성되는 데 주변의 각질형성세포, 섬유아세포 등에서 분비되는 인자의 영향을 받기도 한다(Chen 등, 1991; Kameyama 등, 1993). Melanocyte에는 melanin을 합성하는 효소를 가지고 있는 melanosome이 존재하고, 그 중 tyrosinase는 tyrosine을 DOPA, DOPA quinone으로 산화시키는 과정에 관여하여 melanin 생합 성에 영향을 준다(Iwata 등, 1990). 이에 세포에서 미백효능을 확인하기 위해 melanocyte의 한 종류인 HEM cell에 TW-EA와 positive control인 arbutin을 농도별로 처리하였고 MITF, tyrosinase, TRP-1, TRP-2의 발현을 검증하였다. MITF, tyrosinase, TRP-1, $\mathrm{TRP}-2$ 순서로 $50 \mu \mathrm{g} / \mathrm{mL}$ 의 농도에서 $62,58,34,19 \%$ 의 저해 활성을 나타내었고 positive control인 arbutin은 동일 농도에서 각 각 $33,48,22,8 \%$ 의 억제효과를 보여 TW-EA의 효능이 더 높게 나타났다(Fig. 6).

위 실험결과들을 통해 탁리산의 항산화, 주름 억제, 미백 효 과를 확인함으로써 복합적인 한방처방의 다중 활성을 통한 피 부개선효과를 증명 할 수 있었다. 이는 탁리산의 기능성 화장 품 소재로의 개발 가능성을 보여준다고 사료된다.

\section{초 록}

본 연구에서는 탁리산 열수추출물을 용매 분획하여 항산화, 주 름억제, 미백효과에 대한 활성을 검증하여 화장품 소재로서 이 용가능성을 연구하였다. 용매 분획물로 DPPH radical scavenge, ABTS radical scavenge, elastase, tyrosinase 저해활성을 확인하 였고 에틸아세테이트 분획물(TW-EA)이 가장 높은 저해활성을 나타내었다. 세포내에서의 주름억제, 미백효과를 확인하기 위해 서 western blot을 실시하였고 비교 검증을 위해 사용한 positive contol보다 TW-EA의 억제효과가 뛰어난 것을 확인하 였다. 이러한 결과로 탁리산의 화장품소재로서 적용 가능성을 검증하였다.

\section{Keywords 미백 · 주름억제 · 탁리산 · 항산화 · CCD-986sk HEM}

감사의 글 이 연구는 산업통상자원부 지역특화(주력)산업육성사업(R0005615) 의 일환으로 수행하였음.

\section{References}

Busca R, Ballotti R (2000) Cyclic AMP a key messenger in the regulation of skin pigmentation. Pigment Cell Res 13: 60-69

Carmichael J, DeGraff WG, Gazdar AF, Minna JD, Mitchell JB (1987) Evaluation of a tetrazolium based semiautomated colorimetric assay: assessment of chemosen- sitivity testing. Cancer Res 47: 936-942

Charous SJ, Stricklin GP, Nanney LB Burkey BB (1997) Expression of matrix metalloproteinases and tissue inhibitor of metalloproteinases in head and neck squa-mous cell carcinoma. Ann Oto Rhino 106: 271-278
Chen JS, Wei CI, Marshall MR (1991). Inhibition mechanism of kojic acid on polyphenol oxidase. J Agr Food Chem 39(11): 1897-1901

Choi JH, Kim HM, Song YS, Park SG, Kim JJ, Lee CK (2007) Physiological effects of the cosmetic product containing of saccharomyces fermented modified kyungohkgo extract on human skin. Kor J Herbol 22(4): 227 232

Choi JH, Kim JH, Park SY, Yu MK (2005) Mechanism Study of Takli-San on the Anti-Cancer Action in Mice. J Kor Med Ophthal Otol Dermatol 18(1): 71-81

Choi SJ, Cho EA, Cho EH, Jeong YJ, Ku CS, Ha BJ, Chae HJ (2011) Screening of functional materials from solvent fractions of apple flower leaf extract. KSBB J 26(2): 165-171

Di Girolamo N, Wakefield D, Coroneo MT (2006) UVB mediated induction of cytokines and growth factors in pterygium epithelial cells involves cell surface receptors and intracellular signaling. Invest Ophth Vis Sci 47: 2430-2437

Eun JS, Jeon YK, Yum JY, Suh ES, So JN, Oh CH (1993) Effect of SinhyoTaklee-San on the Proliferation of Fibroblast Cell (Balb/c 3T3). Kor J Pharm 24(2): 159-165

Fisher GJ, Wang ZQ, Datta SC, Varani J, Kang S, Voorhees JJ (1997) Pathophysiology of premature skin aging induced by ultraviolet light. New Engl J Med 337: 1419-1428

Gilchrest BA (1990) Skin aging and photoaging. Dermatol nurs 2(2): 79-82

Ha TK (2009) Inhibitory effect of Fritillaria verticillata Willd. var. thunbergii Baker ethanol extract on melanin biosynthesis. Dissertation, Sangji University

Ha TY (2006) Development of functional food materials for healthy life. Korean J Crop Sci 51: 26-39

Han SB, Kwon SS, Kong BJ, Kim KJ, Park SN (2013) Antioxidative effect and tyrosinase inhibitory activity of the unripened fruit extract of Rubus coreanus Miquel. J Soc Cosmet Sci Kor 39: 295-302

Iwata M, Corn T, Iwata S, Everett MA, Fuller BB (1990) The relationship between tyrosinase activity and skin color in human foreskins. J Invest Dermatol 95: 9-15

Jang YA, Yeo SI, Lee JT (2012) The research of pharmacological activation for Sanguisorbae Radix Fractions as cosmetic material. Kor J Herbol 27(2): 43-46

Kameyama K, Takemura T, Hamada Y, Sakai C, Kondoh S, Nishiyama S, Hearing VJ (1993) Pigment production in murine melanoma cells is regulated by tyrosinase, tyrosinase-related protein 1 (TRP1), DOPAchrome tautomerase (TRP2), and a melanogenic inhibitor. J Invest Dermatol 100(2): 126-131

Kang MS, Kim YM, Kim HT (2016) A Clinical Study for Moisturizing Effects of Herbal Cosmetics Containing Sinhyotakrisan Extracts. J Kor Med Ophthal Otolaryngol Dermatol 29(1): 81-92

Karin SK, Peter B, Jutta W, Gernot H, Weijan M, Lale N, Christian M, Meinhard W (2000) Photoaging of the skin from phenotype to mechanisms. Exp Gerontol 35: 307-316

Kim DI, Kim SH, Choi MS Park SD (2015) A Study on Application of Korean Medical Pre-scriptions Theory in Developing Transdermal Medicine and Korean Medical Cosmetic Prepa-ration Using Oral Herbal Medicine. J Kor Obstet Gynecol 28(3): 74-86

Kim HR, Park GN, Jung BK, Yoon WJ, Jung YH, Chang KS (2016) Antioxidant Activity of Solvent Fractions from Distylium racemosum in Jeju. Kor J Clin Lab Sci 48(2): 62-67

Kim MS, Kim KH, Yook HS (2012) Antioxidative effects of Campanula takesimana Nakai extract. J Kor Soc Food Sci Nutr 41(10): 1331-1337

Kim SH, Yun DC, Kim HT, Ho DS, Yoon KS (2008a) A Clinical Research of Atopic Derma-titis treated by Yeongyuseungmatang in cosmetics. J Korean Med Ophthalmol Otolaryngol Dermatol 21(2): 126-141

Kim YH, Chung CB, Kim JG, Ko KI, Park SH, Kim JH, Eom SY, Kim YS, Hwang YI, Kim KH (2008b) Anti-wrinkle activity of ziyuglycoside I isolated from a Sanguisorba officinalis root extract and its application as a cosmeceutical ingredient. Biosci Biotechnol Biochem 72(2): 303-311

Ko MS, Lee HJ, Kang MJ (2012) Antioxidant Activities and Whitening 
Effects of Extracts from Hippophae rhamnoides L. J East Asian Soc Diet Life 22(6): 812-817

Lee SM (2011) Effects of Angelica gigantis herbal acupuncture extracts on the elastase activity and DPPH and NO scavenging activities. Dissertation, Daegu Haany University

Lee YS, Kwon KJ, Kim MS, Sohn HY (2013) Antimicrobial, antioxidant and anticoagulation activities of Korean radish (Raphanus sativus L.) leaves. Microbiol Biotechnol Letters 41(2): 228-235

Meinhard W, Iliana TP, Lale N, Wenjian M, Lars AS, Ziba RW, Jutta SI, Karin SK (2001) Solar UV irradiation and dermal photoaging. J Photochem Photobiol B Biol 63: 41-51

Park BJ, Onjo M (2008) Antioxidant activities and tyrosinase inhibitory effects of guava (Psidium guajava L.) leaf. Kor J Plant Res 21(5): 408412

Re R, Pellegrini N, Proteggente A, Yang M, Rice-Evans C (1999) Antioxidant activity applying an improved ABTS radical cation decolorization assay. Free Radical Biol Med 26: 1231-1237

Saha B, Singh SK, Sarkar C, Bera R, Ratha J, Tobin DJ, Bhadra R (2006) Activation of the Mitf promoter by lipid-stimulated activation of $\mathrm{p} 38$ stress signalling to CREB. Pigment Cell Res 19: 595-605

Seo JY, Choi HR, Rhie GE, Youn CS, Choi WW, Kim JA, Chung JH, Cho $\mathrm{KH}$, Eun HC (2001) The effect of retinoic acid and vitamin C on the expression of the procollagen a1 (I), tropoelastin, and MMP-1 in human dermal fibroblast. Kor J Invest Dermtaol 8: 23-28

Shimauchi T, Sugita K, Nishio D, Isoda H, Abe S, Yamada Y, Hino R, Ogata M, Kabashima K, Tokura Y (2008) Alterations of serum Th1 and Th2 chemokines by combination therapy of interferon-ã and narrowband UVB in patients with mycosis fungoides. J Dermatol Sci 50: 217-225

So SH, Lee SK, Hwang EI, Koo BS, Han GH, Lee MJ, Chung JH, Kim NM (2008) Mecha-nisms of Korean red ginseng and herb extracts (KTNG0345) for anti-wrinkle activity, J Ginseng Res 32(1): 39-47

Voegeli R (1996) Elastase and tryptase determination on human skin surface. Cosmet Toiletries 111; 51-58

Yaar M, Gilchrest BA (2007) Photoageing: mechanism, prevention and therapy. Br J Dermatol 157: 874-887

Yagi A, Kanbara T, Morinobu N (1986) The effect of tyrosinase inhibition for aloe. Planta medica 3981: 517-519

Yoon I, Wee JH, Moon JH, Ahn TH, Park KH (2003) Isolation and identification of quercetin with antioxidative activity from the fruits of Rubus coreanus Miquel. Kor J Food Sci Technol 35: 499-502

Yoon JY, Lee SY, Jun HJ, Lee JY (2012) Anti-aging effects of solvent fraction from Agrimonia pilosa L. extracts. J Appl Biol Chem 55(1): 35-39

Yun DC, Kim HT, Kim EH, Ho DS (2008) Clinical research of atopic dermatitis treated by Hwangryeonhaedok-Tang in cosmetics. Korean J Ori Physiol Pathol 22(6): 1611-1620 